\title{
A Comparative Study on Socio Economic Impact of Bt cotton and Non-Bt cotton Farm Households in Warangal District of Telangana State, India
}

\author{
S. Kaviraju*, Dinesh Kumar, Nahar Singh and Sanjay Kumar
}

Department of Agricultural Economics, Allahabad School of Agriculture, Sam Higgin Bottom

Institute of Agriculture, Sciences and Technology, Naini, Allahabad, Uttar Pradesh, India

*Corresponding author

\section{A B S T R A C T}

A comparative study of socio economic impact on Bt cotton and Non-Bt cotton was

\section{Key words}

Bt cotton, Non- Bt cotton, Occupation, Assets and Cropping Intensity

Article Info

Accepted:

12 April 2018

Available Online:

10 May 2018 carried out in Warangal district of Telangana State during the year 2016. The study was conducted with the objective to evaluate the socio economic characteristics of both $\mathrm{Bt}$ cotton and Non-Bt cotton farm households. Jangoan block was purposively selected for the study as it was recorded as highest area under Non-Bt and Bt cotton cultivation. Total 120 farm households were surveyed for the study in which 60 farmers were selected from Bt cotton cultivars and another 60 from Non-Bt cotton. Among all crops which were cultivated in the Study area on an average Bt cotton has occupied 0.76 ha and Non Bt cotton occupied 0.72 ha. The cropping intensity is in Bt cotton farm households was 203.7 per cent and in case of Non-Bt cotton farm households it was 196.03 per cent. The average size of farm families are four to five members were common in both Bt and Non-Bt cotton households but it was slightly higher in Bt-cotton than Non-Bt cotton. The total literacy was seems to be high in Bt cotton than Non-Bt cotton households. The literacy rate increasing from small to large both in case of Bt and Non-Bt. Cotton. The sample average of Primary occupation was highest in Non-Bt cotton farm households as against to the Bt cotton households

\section{Introduction}

Cotton (Gossypium sps) the "white gold" and "king of fibers", is cultivated in tropical and subtropical regions of more than seventy countries across the world and enjoys a predominant position amongst all cash crops in India. The major producers of cotton are USA, China, India, Pakistan, Uzbekistan, China, Australia, Greece, Brazil, Egypt and Turkey contributing about 85 per cent of the Global cotton production. Cotton is a major cash crop of India and is the largest producer of cotton in the world accounting for about $26 \%$ of the world cotton production. It has the distinction of having the largest area under cotton cultivation in the world constituting about $38 \%$ to $41 \%$ of the world area under cotton cultivation.

Cotton is grown under rainfed as well as irrigated conditions and the major cotton producing states include Punjab, Haryana, Rajasthan, Madhya Pradesh, Gujarat, Maharashtra, Andhra Pradesh, Karnataka, Telangana and Tamil Nadu. The pest problem 
in cotton is one of the worst among all crops (http://cotcorp.gov.in).

\section{Bt cotton adoption in India}

In India, 162 species of insect pests attack different stages of cotton. The bollworms are most important tissue feeders and highly damaging. Three types of bollworms viz. American bollworm (Helicoverpa armigera), Pink bollworm (Pectionphora gossypiella) and spotted bollworm (Earias vitella), normally referred as bollworm complex are by far the most damaging and loss inducing pests of cotton. Amongst them, Helicoverpa emerged as a key pest all over the country causing as high as $80 \%$ losses in cotton. Lot of efforts have been made for alternative strategies of bollworm management and various nonpesticidal (NPM), restricted pesticidal (IRM) and IPM techniques have been formulated, tested and demonstrated. These are slowly gaining acceptance but so far successes have been restricted and dissemination is slow. Transgenic Bt cotton, which evokes inbuilt resistance in the host, is gaining wider adaptability as a means of avoidance of losses due to bollworm because the technology operates at seed level dissemination and finds quick favour among the users.

Therefore, Bt cotton has already proved useful in countries where it has been introduced earlier. In Indian context also, it is expected to give a wider base to all other protection strategies in cotton. The $\mathrm{Bt}$ is a short form of ubiquitous soil bacterium Bacillus thuringiensis. This bacterium is gram positive and spore forming that forms parasporal crystals during stationary phase of its growth cycle. The synthesized crystalline proteins called 'endotoxins' are highly toxic to certain insects. The decision of the Genetic Engineering Approval committee (GEAC) of Government of India clearing the release of $\mathrm{Bt}$ cotton for commercial cultivation during 2002-2003 crop season, is considered as one of the major milestones in the history of cotton improvement in India.

Bt cotton adoption in India show that the technology leads to significant pesticide reductions, yield gains, and income increases on average. $\mathrm{Bt}$ technology might not be suitable for all farmers because pest pressure and access to effective alternatives vary from case to case (Qaim et al., 2005). The non-Bt cotton farmers use chemical fertilizers, organic manures and bullock labour excessively which result in a lower net returns. Technology has been found the major contributor to the total productivity difference between Bt and non- Bt cottons. Seed cost, yield of Bt cotton and cost of plant protection have been found to greatly influence the probability of adoption of Bt cotton (Kiresur et al., 2011). Farmers that used cotton engineered to produce the Bacillus thuringiensis (Bt) substantially reduced the use of pesticide without reducing the output/ha. or quality of cotton. This resulted in substantial economic benefits for small farmers (pray et al., 2001). Bt variety generally resulted in a per hectare increase in yields, value of output and reduction of pesticide costs which outweighed the increase in seed costs to give a substantial increase in gross margins (Ismael et al., 2001). To evaluate and propose interventions in cropping pattern of any area a comprehensive study and understanding of socio economic conditions of farming livelihoods is essential. In Warangal district of Telangana state a case study was taken up to evaluate the socio economic impact of Bt cotton and Non-Bt cotton on Different size farm households.

\section{Materials and Methods}

A detailed survey on Socio Economic profile of $\mathrm{Bt}$ cotton and Non-Bt cotton Farm Households in Warangal District of Telangana State was carried out in Jangoan block during the year 2016. A purposive sampling 
technique was adopted for the survey. As a result Jangoan block was selected purposively based on highest area under Non-Bt and Bt cotton cultivation. The survey was conducted in six villages of Jangoan block. In each of these six villages $10 \mathrm{Bt}$ cotton and 10 Non-Bt cotton households were selected as a result 60 $\mathrm{Bt}$ and 60 Non $\mathrm{Bt}$ cotton growing households selected for the study. Total 120 farm households were surveyed for the study. In each village farmers were selected in ascending order on the basis of area under Bt. cotton and Non-Bt cotton cultivation and these farmers were again classified in three different size groups on the basis of area under Bt. and non Bt. cotton cultivation viz.,

First group: Small households - less than 1 ha;

Second group: Medium households -1 ha to less than 2 ha and

Third group: Large households - More than 2 ha

\section{Cropping intensity formula}

Cropping intensity $=($ Gross cropped area $/$ Net sown area) x 100

A combination of descriptive statistics, mathematical and statistical techniques was used to achieve the objectives. Descriptive statistics like sum, average, percentage and ratio were calculated to examine the socio economic characteristics

\section{Results and Discussion}

\section{Cropping pattern followed by farmers}

Out of $60 \mathrm{Bt}$ cotton Farm households which 34 farm households were categorized as small, 18 medium and 08 large households respectively. Similarly in case of the Non-Bt cotton 28 farm households were categorized as small, 19 medium and 13 were large, respectively. Altogether 120 respondents were selected for study. Sample average of the total cultivated holdings for $\mathrm{Bt}$ cotton farm households was 1.31 ha. and it for Non-Bt cotton recorded as 1.39 ha. It could also be seen that land utilization pattern in different crops. The crops sown in Kharif season in this area were cotton, Paddy and Maize.

Among all these crops on an average Bt cotton has occupied 0.76 ha and Non Bt cotton occupied 0.72 ha. The area allocated to Both Bt and Non-Bt cotton was seems to be higher than the area allocated other crops due to low rainfall in the study area in particular season influencing the farmers to grow cotton crop under rain fed condition. The average total sown area for Bt cotton farm households was 2.58 ha. and for Non-Bt cotton farm households it was $2.63 /$ ha. The cropping intensity is an indicator of the efficient use of land. The sample average Cropping intensity in $\mathrm{Bt}$ cotton farm households was 203.7 per cent and in case of Non-Bt cotton farm households it was 196.03 per cent (Table 1).

\section{Family composition of different size farm groups}

The average family size of all households did not vary much but 4 to 5 members were common among small, medium and large farm households in both Bt and Non-Bt cotton farm groups. The composition of an average size of the farm families according to sex and age composition is indicated in Table 2.

The sample average of male population in $\mathrm{Bt}$ and Non-Bt cotton farm households was 55.07 and 58.50 percent respectively. The sample average of female population in Bt and Non$\mathrm{Bt}$ cotton farm households was 44.93 and 41.50 per cent respectively. The average size of farm families are four to five members were common in both $\mathrm{Bt}$ and Non-Bt cotton households but it was slightly higher in Btcotton than Non-Bt cotton. 
Table.1 Detail description of cultivated holdings of farm in different size farm groups in 2016 (Area in hectares)

\begin{tabular}{|c|c|c|c|c|c|c|c|c|c|c|}
\hline \multirow[t]{2}{*}{ S.no } & \multirow{2}{*}{\multicolumn{2}{|c|}{ Particulars }} & \multicolumn{4}{|c|}{ Bt cotton Farm House Hold } & \multicolumn{4}{|c|}{ Non-Bt cotton Farm House Hold } \\
\hline & & & Small & Medium & Large & $\begin{array}{l}\text { Sample } \\
\text { Average }\end{array}$ & Small & Medium & Large & $\begin{array}{l}\text { Sample } \\
\text { Average }\end{array}$ \\
\hline 1 & \multicolumn{2}{|c|}{$\begin{array}{c}\text { Size of farms } \\
\text { group } \\
\text { (in numbers) }\end{array}$} & 34 & 18 & 8 & 60 & 28 & 19 & 13 & 60 \\
\hline 2 & \multicolumn{2}{|c|}{$\begin{array}{l}\text { Average size of } \\
\text { cultivated holdings } \\
\text { in Hectare }\end{array}$} & 0.92 & 1.36 & 2.87 & 1.31 & 0.82 & 1.4 & 2.63 & 1.39 \\
\hline \multirow[t]{2}{*}{3} & \multicolumn{6}{|c|}{ Land utilization in different crops (sown area in ha) } & & & & \\
\hline & \multicolumn{6}{|l|}{ Kharif } & & & & \\
\hline \multirow[t]{4}{*}{ i } & 1 & Cotton & 0.52 & 0.81 & 1.67 & 0.76 & 0.45 & 0.64 & 1.58 & 0.72 \\
\hline & 2 & Paddy & 0.21 & 0.25 & 0.52 & 0.26 & 0.19 & 0.26 & 0.37 & 0.25 \\
\hline & 3 & Maize & 0.12 & 0.16 & 0.26 & 0.15 & 0.12 & 0.31 & 0.45 & 0.25 \\
\hline & 4 & others & 0.07 & 0.14 & 0.42 & 0.14 & 0.06 & 0.19 & 0.23 & 0.14 \\
\hline \multirow[t]{5}{*}{ ii } & \multicolumn{10}{|l|}{ Rabi } \\
\hline & 1 & cotton & 0 & 0 & 0 & 0 & 0 & 0 & 0 & $\mathbf{0}$ \\
\hline & 2 & Chilli & 0.21 & 0.27 & 0.64 & 0.29 & 0.18 & 0.25 & 0.64 & 0.3 \\
\hline & 3 & Maize & 0.15 & 0.13 & 0.37 & 0.17 & 0.11 & 0.36 & 0.28 & 0.23 \\
\hline & 4 & Others & 0.04 & 0.1 & 0.19 & 0.08 & 0.08 & 0.15 & 0.13 & 0.11 \\
\hline \multirow[t]{5}{*}{ iii } & \multicolumn{10}{|c|}{ Summer } \\
\hline & 1 & Paddy & 0.25 & 0.31 & 0.42 & 0.29 & 0.16 & 0.24 & 0.26 & 0.21 \\
\hline & 2 & Pulses & 0.21 & 0.18 & 0.27 & 0.21 & 0.22 & 0.21 & 0.18 & 0.21 \\
\hline & 3 & Maize & 0.09 & 0.14 & 0.11 & 0.11 & 0.12 & 0.06 & 0.21 & 0.12 \\
\hline & 4 & Others & 0.12 & 0.12 & 0.04 & 0.11 & 0.04 & 0.08 & 0.06 & 0.06 \\
\hline 4 & \multicolumn{2}{|c|}{ Total sown area } & 1.99 & 2.66 & 4.91 & 2.58 & 1.73 & 2.75 & 4.39 & 2.63 \\
\hline 5 & \multicolumn{2}{|c|}{ Cropping intensity } & 216 & 195 & 171 & 203.7 & 210 & 196 & 166 & 196.03 \\
\hline
\end{tabular}

Table.2 Detail description of male and female ratio sample size of farm families in 2016

\begin{tabular}{|c|c|c|c|c|c|c|c|c|c|}
\hline \multirow[t]{2}{*}{ Sl. No } & \multirow[t]{2}{*}{ Particulars } & \multicolumn{4}{|c|}{ Bt cotton Farm House Hold } & \multicolumn{4}{|c|}{ Non-Bt cotton Farm House Hold } \\
\hline & & Small & Medium & Large & $\begin{array}{c}\text { Sample } \\
\text { Average }\end{array}$ & Small & Medium & Large & $\begin{array}{l}\text { Sample } \\
\text { Average }\end{array}$ \\
\hline 1 & Male & $\begin{array}{l}2.55 \\
(58)\end{array}$ & $\begin{array}{c}2.77 \\
(56.82)\end{array}$ & $\begin{array}{c}2.75 \\
(59.46)\end{array}$ & $\begin{array}{c}2.53 \\
(\mathbf{5 5 . 0 7})\end{array}$ & $\begin{array}{c}2.82 \\
(57.25)\end{array}$ & $\begin{array}{c}2.89 \\
(57.9)\end{array}$ & $\begin{array}{c}2.9 \\
(62.3)\end{array}$ & $\begin{array}{c}2.86 \\
(\mathbf{5 8 . 5})\end{array}$ \\
\hline 2 & Female & $\begin{array}{l}1.88 \\
(42)\end{array}$ & $\begin{array}{c}2.11 \\
(43.18)\end{array}$ & $\begin{array}{c}1.87 \\
(40.54)\end{array}$ & $\begin{array}{c}2.06 \\
(44.93)\end{array}$ & $\begin{array}{c}2.1 \\
(42.75)\end{array}$ & $\begin{array}{c}2.1 \\
(42.1)\end{array}$ & $\begin{array}{r}1.76 \\
(37.7)\end{array}$ & $\begin{array}{c}2.03 \\
(41.5)\end{array}$ \\
\hline & $\begin{array}{l}\text { Average size of } \\
\text { farm families }\end{array}$ & $\begin{array}{c}4.44 \\
(100 \%)\end{array}$ & $\begin{array}{c}4.88 \\
(100 \%)\end{array}$ & $\begin{array}{c}4.62 \\
(100 \%)\end{array}$ & $\begin{array}{c}\mathbf{4 . 6} \\
(100 \%)\end{array}$ & $\begin{array}{c}4.92 \\
(100 \%)\end{array}$ & $\begin{array}{c}5 \\
(100 \%)\end{array}$ & $\begin{array}{c}4.69 \\
(100 \%)\end{array}$ & $\begin{array}{c}\mathbf{4 . 9} \\
(100 \%)\end{array}$ \\
\hline
\end{tabular}

Note: Figures in parentheses are percentage to the respective column totals. 
Table.3 Educational status of different size of farm households

\begin{tabular}{|c|c|c|c|c|c|c|c|c|c|}
\hline \multirow{2}{*}{$\begin{array}{l}\text { S. } \\
\text { no }\end{array}$} & \multirow[t]{2}{*}{ Particulars } & \multicolumn{4}{|c|}{ Bt cotton farm household } & \multicolumn{4}{|c|}{ Non-Bt cotton farm household } \\
\hline & & Small & Medium & Large & $\begin{array}{c}\text { Sample } \\
\text { Average }\end{array}$ & Small & Medium & Large & $\begin{array}{c}\text { Sample } \\
\text { Average }\end{array}$ \\
\hline \multirow[t]{2}{*}{1} & \multirow{2}{*}{$\begin{array}{l}\text { Average size } \\
\text { of farm } \\
\text { families }\end{array}$} & 4.44 & 4.88 & 4.62 & 4.6 & 4.92 & 5 & 4.62 & 4.9 \\
\hline & & & & & & & & & \\
\hline \multirow[t]{2}{*}{2} & \multicolumn{9}{|c|}{ Educational status } \\
\hline & & 0.7 & 1 & 0.87 & 0.81 & 1.14 & 0.63 & 0.46 & 0.83 \\
\hline \multirow[t]{2}{*}{ i } & Primary & (15.9) & $(20.45)$ & $(18.92)$ & (17.75) & (23.19) & 12.63 & 9.81 & 17 \\
\hline & \multirow{2}{*}{$\begin{array}{l}\text { Middle High } \\
\text { school }\end{array}$} & 0.94 & 1.22 & 1 & 1.03 & 0.96 & 1.47 & 0.61 & 1.05 \\
\hline \multirow[t]{2}{*}{ ii } & & (21.19) & $(25.00)$ & $(21.62)$ & (22.46) & (19.56) & 29.48 & 13.1 & 21.42 \\
\hline & \multirow[t]{2}{*}{ Intermediate } & 1.41 & 1.5 & 1.25 & 1.41 & 0.92 & 0.94 & 1.07 & 0.96 \\
\hline \multirow[t]{2}{*}{ iii } & & $(31.78)$ & $(30.68)$ & $(27.02)$ & (30.80) & $(18.84)$ & 18.95 & 23 & 19.72 \\
\hline & \multirow{2}{*}{$\begin{array}{l}\text { Graduation } \\
\text { and Above }\end{array}$} & 0.7 & 0.66 & 1.12 & 0.75 & 0.78 & 1.36 & 1.92 & 1.21 \\
\hline iv & & $(15.9)$ & (13.63) & $(24.33)$ & (16.31) & $(15.95)$ & 27.36 & 40.98 & 24.82 \\
\hline \multirow[t]{3}{*}{3} & \multirow[t]{2}{*}{ Total literacy } & 3.76 & 4.38 & 4.25 & 4.01 & 3.82 & 4.42 & 4.07 & 4.07 \\
\hline & & $(84.77)$ & (89.76) & $(91.89)$ & $(87.31)$ & (77.54) & 88.42 & 86.89 & 83.30 \\
\hline & & 0.67 & 0.5 & 0.37 & 0.56 & 1.1 & 0.57 & 0.53 & 0.81 \\
\hline 4 & Total illiteracy & $(15.23)$ & (10.29) & $(8.11)$ & (12.69) & (22.46) & 11.58 & 13.11 & 16.70 \\
\hline
\end{tabular}

Note: Figures in parentheses are percentage to the respective column total

Table.4 Detail Description of occupational distribution of farm families

\begin{tabular}{|c|c|c|c|c|c|c|c|c|c|}
\hline \multirow[t]{2}{*}{ S .No } & \multirow[t]{2}{*}{ Particulars } & \multicolumn{4}{|c|}{ Bt cotton Farm House Hold } & \multicolumn{4}{|c|}{ Non-Bt cotton Farm House Hold } \\
\hline & & Small & Medium & Large & $\begin{array}{l}\text { Sample } \\
\text { Average }\end{array}$ & Small & Medium & Large & $\begin{array}{c}\text { Sample } \\
\text { Average }\end{array}$ \\
\hline 1 & $\begin{array}{l}\text { Size of farms } \\
\text { group } \\
\text { (in numbers) }\end{array}$ & $\begin{array}{c}34 \\
(100)\end{array}$ & $\begin{array}{c}18 \\
(100)\end{array}$ & $\begin{array}{c}8 \\
(100)\end{array}$ & $\begin{array}{c}60 \\
(100)\end{array}$ & $\begin{array}{c}28 \\
(100)\end{array}$ & $\begin{array}{c}19 \\
(100)\end{array}$ & $\begin{array}{c}13 \\
(100)\end{array}$ & $\begin{array}{c}60 \\
(100)\end{array}$ \\
\hline 2 & $\begin{array}{l}\text { One occupation } \\
\text { (Primary } \\
\text { occupation) }\end{array}$ & $\begin{array}{c}9 \\
(26.47)\end{array}$ & $\begin{array}{c}6 \\
(36.36)\end{array}$ & $\begin{array}{c}7 \\
(33.33)\end{array}$ & $\begin{array}{c}17 \\
(28.34)\end{array}$ & $\begin{array}{c}12 \\
(42.85)\end{array}$ & $\begin{array}{c}8 \\
(42.10)\end{array}$ & $\begin{array}{c}6 \\
(46.15)\end{array}$ & $\begin{array}{c}26 \\
(43.34)\end{array}$ \\
\hline 3 & $\begin{array}{l}\text { Two occupation } \\
\text { (Secondary } \\
\text { occupation) }\end{array}$ & $\begin{array}{c}12 \\
(35.30)\end{array}$ & $\begin{array}{c}8 \\
(36.36)\end{array}$ & $\begin{array}{c}7 \\
(38.88)\end{array}$ & $\begin{array}{c}23 \\
(38.33)\end{array}$ & $\begin{array}{c}7 \\
(25.00)\end{array}$ & $\begin{array}{c}6 \\
(31.59)\end{array}$ & $\begin{array}{c}4 \\
(30.78)\end{array}$ & $\begin{array}{c}17 \\
(28.33)\end{array}$ \\
\hline 4 & $\begin{array}{c}\text { Three occupation } \\
\text { (Tertiary } \\
\text { occupation) }\end{array}$ & $\begin{array}{c}13 \\
(38.23)\end{array}$ & $\begin{array}{c}6 \\
(27.27)\end{array}$ & $\begin{array}{c}5 \\
(27.77)\end{array}$ & $\begin{array}{c}20 \\
(33.33)\end{array}$ & $\begin{array}{c}9 \\
(32.15)\end{array}$ & $\begin{array}{c}5 \\
(26.31)\end{array}$ & $\begin{array}{c}3 \\
(23.07)\end{array}$ & $\begin{array}{c}17 \\
(28.33)\end{array}$ \\
\hline
\end{tabular}


Table.5 Details value of asset position of farmers

\begin{tabular}{|c|c|c|c|c|c|c|c|c|c|}
\hline \multirow[t]{2}{*}{ S.No } & \multirow[t]{2}{*}{ Particulars } & \multicolumn{4}{|c|}{ Bt cotton Farm Households } & \multicolumn{4}{|c|}{ Non-Bt cotton Farm Households } \\
\hline & & Small & Medium & Large & $\begin{array}{l}\text { Sample } \\
\text { Average }\end{array}$ & Small & Medium & Large & $\begin{array}{l}\text { Sample } \\
\text { Average }\end{array}$ \\
\hline \multirow[t]{2}{*}{1} & \multirow[t]{2}{*}{ Land } & 16,824 & 29,289 & 35,637 & 27,250 & 15,630 & 38,970 & 62,570 & 39,057 \\
\hline & & $(34.70)$ & (32.67) & (19.12) & (28.83) & (32.38) & (34.88) & (32.08) & (33.11) \\
\hline \multirow[t]{2}{*}{2} & \multirow{2}{*}{$\begin{array}{c}\text { Farm } \\
\text { buildings }\end{array}$} & 9,567 & 22,560 & 26,795 & 19,641 & 9,850 & 28,127 & 37,961 & 25,313 \\
\hline & & (19.74) & (25.18) & (14.38) & (19.77) & $(20.40)$ & (25.16) & (19.47) & (21.17) \\
\hline \multirow[t]{2}{*}{3} & \multirow{2}{*}{$\begin{array}{c}\text { Farm } \\
\text { machinery } \\
\text { \&equipments }\end{array}$} & 8,261 & 19,561 & 98,261 & 42,028 & 8,550 & 16,327 & 68,734 & 31,204 \\
\hline & & (17.04) & $(21.82)$ & $(52.75)$ & $(30.54)$ & (17.72) & (14.62) & (35.24) & $(22.53)$ \\
\hline \multirow[t]{2}{*}{4} & \multirow{2}{*}{ Live stock } & 13,821 & 18,221 & 25,633 & 19,225 & 14,234 & 28,329 & 25,776 & 22,780 \\
\hline & & $(28.52)$ & (20.33) & $(13.75)$ & (20.87) & $(29.50)$ & $(25.34)$ & $(13.21)$ & $(23.00)$ \\
\hline \multirow{2}{*}{\multicolumn{2}{|c|}{ Total value }} & 48,473 & 89,631 & $1,86,326$ & $1,08,143$ & 48,264 & $1,11,753$ & $1,95,401$ & 97,208 \\
\hline & & $(100)$ & $(100)$ & $(100)$ & $(100)$ & $(100)$ & $(100)$ & $(100)$ & $(100)$ \\
\hline
\end{tabular}

Detail description of literacy of farm families

The analysis has indicated that among different size farm groups on an average 17.75 percent of farm families had primary education, 22.46 percent middle high school, 30.8 percent intermediate and 16.3 percent graduates in Bt cotton households. The total literacy and illiteracy rate of $\mathrm{Bt}$ cotton households was recorded as 87.31 and 12.69 percent respectively. However as the size of the farm increases literacy rate also increasing from small to large households in Bt cotton. As regards to the Non- Bt cotton households in different size farm groups on an average 17 percent of farm families had primary education, 21.42 percent middle high school, 19.72 percent intermediate education, 24.82 percent having education up to graduation. The total literacy and illiteracy rate of $\mathrm{Bt}$ cotton households was recorded as 83.30 and 16.7 percent respectively. The total literacy was seems to be high in Bt cotton than Non$\mathrm{Bt}$ cotton households. The literacy rate increasing from small to large both in case of Bt and Non-Bt. Cotton (Table 3).

\section{Occupation details}

The size of the farms group in numbers for $\mathrm{Bt}$ cotton farm households in small, medium, large size of farms were 34,18 and 8 respondents respectively. The size of farms group numbers for Non-Bt cotton farm household in small, medium, large size of farms were 28, 19 and 13 respondents respectively. The sample average of Primary occupation was highest in Non-Bt cotton farm households (43.34 per cent) and 28.34per cent of Bt cotton farm households were engaged with primary occupation. The sample average of Secondary occupation for Bt cotton and Non-Bt cotton farm households was 38.33 and 28.33 percent respectively. The sample average of Tertiary occupation for Bt cotton and Non-Bt cotton farm households was 33.33 per cent and 28.33 per cent respectively

\section{Asset position of farmers}

Farm assets include land, farm buildings, farm machinery and equipment, livestock, depreciation on farm buildings and depreciation on farm machinery and 
equipment per year. Sample average value for land, farm buildings, farm machinery and equipment and the livestock was Rs.27,250, Rs.19,641, Rs.42,368 and Rs.19,225 respectively. In Non-Bt cotton farm households Sample average value for land, farm buildings, farm machinery and equipment and the livestock was Rs.39,057, Rs25,313, Rs 31,204 and Rs22, 780 respectively.

The results of socio economic characteristics show impact on adoption of any new interventions in crop production and technology. According to the results the area under Bt cotton was slightly higher than the area under Non-Bt cotton. But totally area allocated to cotton was higher than the other crops cultivated in the study area. The average family size of all households did not vary much 4 to 5 members were common in both $\mathrm{Bt}$ and Non-Bt cotton households. It was also found that illiteracy is higher in Non-Bt cotton $(16.70$ percent $)$ households as compared to the Bt cotton households(12.69 percent) indicating that these less illiteracy of Non-Bt cotton households making them pay less attention on adoption of new interventions in agriculture as like $\mathrm{Bt}$ cotton. Primary occupation was highest in Non-Bt cotton farm households as against to the $\mathrm{Bt}$ cotton households indicating that Non-Bt cotton farmers concentration was directed only on one occupation (primary occupation). The total average value of assets was found to be higher at Bt-Cotton households as compared to the Non-Bt cotton households.

\section{References}

Carl pray and Danmeng MA (2001), Impact of $\mathrm{Bt}$ cotton on china, World Development vol no.29, No.5, pp 813$825,2001$.

www.cotcorp.gov.in ( Cotton Corporation of India)

Kiresur, V.R., and Manjunath Ichangi (2011), Socio-Economic Impact of Bt Cotton-A Case Study of Karnataka, Agricultural Economics Research Review, Vol. 24 January-June 2011 pp 67-81.

Matin Qaim, Arjun Subramanian, Gopal Naik and David Zilberman (2006), Adoption of $\mathrm{Bt}$ cotton and impact variability: Insights from India. Review of Agricultural Economics-Volume 28, Number 1-Pages 48-58.

Yousouf Ismael, Richard Bennett and Stephen Morse (2001), "Farm level impact of Bt cotton in South Africa." Biotechnology and Development Monitor, No. 48, p. 15-19.

\section{How to cite this article:}

Kaviraju S., Dinesh Kumar, Nahar Singh and Sanjay Kumar. 2018. A Comparative Study on Socio Economic Impact of Bt cotton and Non-Bt cotton Farm Households in Warangal District of Telangana State, India. Int.J.Curr.Microbiol.App.Sci. 7(05): 1561-1567. doi: https://doi.org/10.20546/ijcmas.2018.705.185 